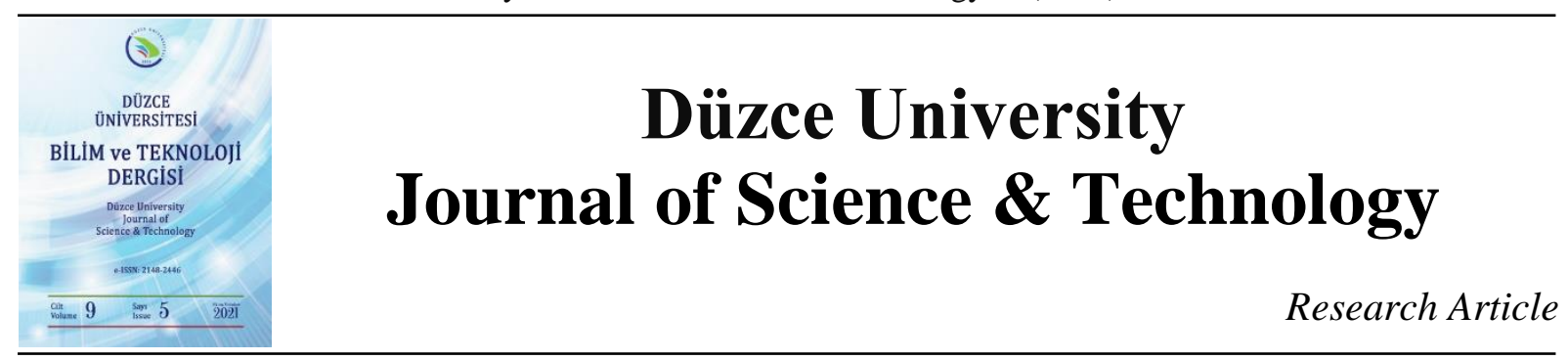

\title{
Mechanical, Thermal and Surface Properties of a New Kind of Polybenzoylthiourea
}

\author{
(iD Gülşah KURT ${ }^{\mathrm{a}, *}$ \\ ${ }^{a}$ Department of Chemistry, Faculty of Arts and Sciences, AksarayUniversity, Aksaray, TURKEY \\ * Corresponding author e-mail:gkurt81@gmail.com
}

DOI: $10.29130 /$ dubited.878203

\begin{abstract}
A new kind of polybenzoylthiourea polymer (PBTU) was synthesized through a polycondensation reaction between 3,5-diamino-1,2,4-triazole and tereftaloyl diisothiocyanate in poly(ethyleneglycol)dimethylether (PEG) as the phase transfer catalyst. Obtained polymer was highly soluble in organic solvents including N,N-dimethyl formamide (DMF) and dimethyl sulfoxide (DMSO) in contrast to the insoluble nature of similar benzoyl thiourea polymers reported in the literature. Solubility of the obtained polymer allowed us to measure the molecular weight of the obtained samples by gel permeation chromatography (GPC) analysis. GPC analysis results interestingly showed bimodal molecular weight distribution probably due to the oligomeric PEG residuals during the workup procedure. Structure of the obtained polymer was characterized by ${ }^{1} \mathrm{H} N M R,{ }^{13} \mathrm{C}$ NMR and elemental analysis. The glass transition temperature $\left(\mathrm{T}_{\mathrm{g}}\right)$ and the melting temperature $\left(\mathrm{T}_{\mathrm{m}}\right)$ of the polymer was observed at $229^{\circ} \mathrm{C}$ and $304^{\circ} \mathrm{C}$, respectively. Total pore volume and surface area of the polymer were calculated as $0.292 \mathrm{~cm}^{3} / \mathrm{g}$ and $17.773 \mathrm{~m}^{2} / \mathrm{g}$, respectively. Hardness and elastic modulus of the obtained PBTU capsule were measured respectively as $2.353 \mathrm{GPa}$ and $0.136 \mathrm{GPa}$ using nanoindentation technique.
\end{abstract}

Keywords:Polybenzoylthiourea, Polycondensation, Tereftaloyl diisothiocyanate, 3,5-Diamino-1,2,4-triazole, Nanoindentation

\section{Yeni Bir Polibenzoiltiyoüre'nin Mekanik, Termal ve Yüzey Özellikleri}

\begin{abstract}
ÖZ
Yeni bir polibenzoiltiyoüre polimeri (PBTU), faz transfer katalizörü olarak poli(etilenglikol)dimetileter içerisinde 3,5-diamino-1,2,4-triazol ve tereftaloil diizotiyosiyanat'in polikondenzasyon reaksiyonu ile sentezlendi. Elde edilen polimer, literatürde bildirilen çözünürlüğü oldukça az olan benzer benzoiltiyoüre polimerlerinin aksine, N,N-dimetilformamit (DMF) ve dimetil sülfoksit (DMSO) gibi organik çözücüler içinde çözünmektedir. Elde edilen polimerin yüksek çözünürlüğü sayesinde, polimer numunesinin moleküler ağırlığ1, jel geçirgenlik kromatografisi (GPC) ile analiz edilebilmiştir. GPC analizi sonuçları ilginç bir şekilde, iki modlu moleküler ağırlık dağılımını göstermiştir, buda muhtemelen deneysel işlem esnasında ürün içerisinde oligomerik artıkların kaldığını göstermektedir. Elde edilen polimerin yapısı, ${ }^{1} \mathrm{H}$ NMR, ${ }^{13} \mathrm{C}$ NMR ve elementel analiz ile karakterize edildi. Polimerin camsı geçiş sıcaklığı $\left(T_{\mathrm{g}}\right)$ ve erime noktası $\left(T_{\mathrm{m}}\right)$ sirasıyla $229^{\circ} \mathrm{C}$ ve $304^{\circ} \mathrm{C}$ de gözlendi. Polimerin toplam gözenek hacmi ve yüzey alanı sırasıyla $0.292 \mathrm{~cm}^{3} / \mathrm{g}$ ve $17.773 \mathrm{~m}^{2} / \mathrm{g}$ olarak hesapland1. Elde edilen PBTU kapsülün sertliği ve elastik modülü nanoindentasyon tekniği kullanılarak sırasıyla 2.353 GPa ve $0.136 \mathrm{GPa}$ olarak ölçüldü.
\end{abstract}

Anahtar Kelimeler: Polibenzoiltiyoüre, Polikondenzasyon, Tereftaloil diizotiyosiyanat, 3,5-Diamino-1,2,4triazol, Nanoindentasyon 


\section{INTRODUCTION}

Benzoylthioureas are important class of compounds due to their semi- or fully aromatic structures, resonance characters, coordination properties with metal ions, hydrophilic properties, high dipole moment, different crystal structures with different dipole moments, redox properties and isomeric structures. These materials can be used in a variety of analytical and environmental applications due to their biological activities, coordination properties with toxic, radio active or heavy metal ions.

Benzoylthioureas have potentially two donor atoms, $\mathrm{O}$ and $\mathrm{S}$. Their well-known properties are their complexation with metal ions [1-5]. $\mathrm{d}^{8}$ and $\mathrm{d}^{9}$ are versatile ligands capable of forming stable complexes with a large number of transition metals, such as giving square planar complexes with metal ions. In addition to being an important class of compounds in the field of coordination chemistry with its rich coordination properties, the sorption properties of benzoylthioureas in selective recovery and preconcentration applications are also remarkable [6]. Polymeric benzoylthiourea structures can be considered as having superior properties in terms of separation, recovery and convenience. Utilizations of benzoylthiourea compounds in membrane systems are also very important [7].

Here, we report a new kind of polybenzoylthiourea polymer (PBTU) synthesized through polyconden sation reaction between 3,5-diamino-1,2,4-triazole and tereftaloyl diisothiocyanate in poly(ethylene glycol)dimethylether as the phase transfer catalyst. While different polybenzoylthiourea derivatives [8] are insoluble in any organic solvents, obtained PBTU is highly soluble in solvents including DMSO and DMF, and show a glass transition temperature. With the synthesis of PBTU, a new polybenzoylthiourea containing triazole and thiourea units in the backbone was synthesized. When PBTU was compared with BTP1 and BTP2 polymers reported in the literature, the main difference was the existence of the triazole unit in the PBTU chain [8].The triazole ring is a heterocyclic aromatic compound with large dipole moment, hydrogen bonding ability and biological activity [9-11]. Due to its aromatic structure, the triazole ring shows high stability. Polymer films containing triazole ring in the backbone exhibited high thermal and mechanical properties. It has been reported in the literature that triazole-containing polymers can be dissolved in polar organic solvents including DMSO and DMF even at room temperature [12]. In addition, the synthesis of highly-soluble and thermally stable polytriazole membranes with improved mechanical properties using appropriate processes were reported in the literature [13]. In the literature, there are no research on the mechanical properties of polybenzoylthioureas and there is a limited number of research about the surface properties of polybenzoylthioureas. This study investigated both surface and mechanical properties of the new polybenzoylthiourea polymer (PBTU) containing triazole unit in the backbone. Aromatic structures in the repeating units of the product with thiourea functional groups provide more hardness. Nanoidentation technique is used to characterize the mechanical properties of PBTU capsules.

\section{EXPERIMENTAL SECTION}

\section{A.EXPERIMENTAL}

\section{A.1.Chemicals}

Potassium thiocyanate (Sigma-Aldrich, catalog\#333-20-0), terephthaloyl chloride (Sigma-Aldrich, catalog\#100-20-9), 3,5-diamino-1,2,4-triazole (Sigma-Aldrich, catalog\#1455-77-2), 4,4-diaminodiphenylmethane (Sigma-Aldrich, catalog\#101-77-9), 1,5-diaminonaphthalene (Sigma-Aldrich, catalog\#2243-62-1), dichloromethane (anhydrous $>99,8 \%$; Sigma-Aldrich, catalog\#75-09-2), diethylether(anhydrous $>99 \%$; Sigma-Aldrich, catalog\#60-29-7), poly(ethyleneglycol)dimethylether $\left(M_{\mathrm{n}} \sim 500\right.$; Merck, catalog\#24991-55-7) used as the phase transfer catalyst were purchased with high-grade purities and used without further purification 


\section{A.2.Experimental Procedures}

BTP1 (benzoylthiourea polymer 1) and BTP2 (benzoylthiourea polymer 2) polymers were synthesized and characterized according to the literature [8] to compare their mechanical properties with PBTU polymer.

\section{A.2.1.Preparation of PBTU}

$2.5 \mathrm{~g}(0.025 \mathrm{~mol})$ potassium thiocyanate and $2.5 \mathrm{~g}(0.012 \mathrm{~mol})$ of terephthaloyl chloride was dissolved in dichloromethane. $1 \mathrm{~mL}$ of poly(ethyleneglycol)dimethylether (average molecular weight $M_{\mathrm{n}} \sim 500$ ) was added to the mixture. After $2 \mathrm{~h}$ stirring at room temperature, the obtained mixture was filtered and obtained precipitate (potassium chloride) was removed. $40 \mathrm{~mL}$ of terephthaloyl diisothiocyanate solution was obtained [8]. To a solution of 3,5-diamino-1,2,4-triazole $(2.486 \mathrm{~g}, 0.024 \mathrm{~mol})$ in $40 \mathrm{~mL}$ of dichloromethane, terephthaloyl diisothiocyanate filtrates in 1:1 stoichiometry (40 mL) was dropwise added. $1 \mathrm{~mL}$ of poly(ethyleneglycol)dimethylether was added to the mixture as phase transfer catalyst. Reaction occurred within minutes. It was then refluxed for $24 \mathrm{~h}$ at $50^{\circ} \mathrm{C}$. The yellow precipitated polymer was filtered, washed several times with methylene chloride, water and diethylether and dried at $100^{\circ} \mathrm{C}$. The synthesis route of the PBTU was shown Figure 1.

Color:Yellow. Elemental analysisfound for: $\left[\mathrm{C}_{12} \mathrm{H}_{9} \mathrm{~N}_{7} \mathrm{O}_{2} \mathrm{~S}_{2}\right]_{\mathrm{n}}: \mathrm{C}: 40.4, \mathrm{H}: 3.63, \mathrm{~S}: 14.07, \mathrm{~N}: 27.5 .{ }^{1} \mathrm{H}$ NMR(400 MHz, DMSO-d6, $\delta$ ppm):12.5-11.6 (1H,m,N-H), $10.0(1 \mathrm{H}, \mathrm{s}, \mathrm{N}-\mathrm{H}), 8.80-7.00(4 \mathrm{H}, \mathrm{m}, \mathrm{Ar}-$ H). ${ }^{13} \mathrm{C}$ NMR(100 MHz, DMSO d6, סppm):172,167,166,162,158,155,138, 136,134,130,129,128,127.

\section{RESULTS AND DISCUSSION}

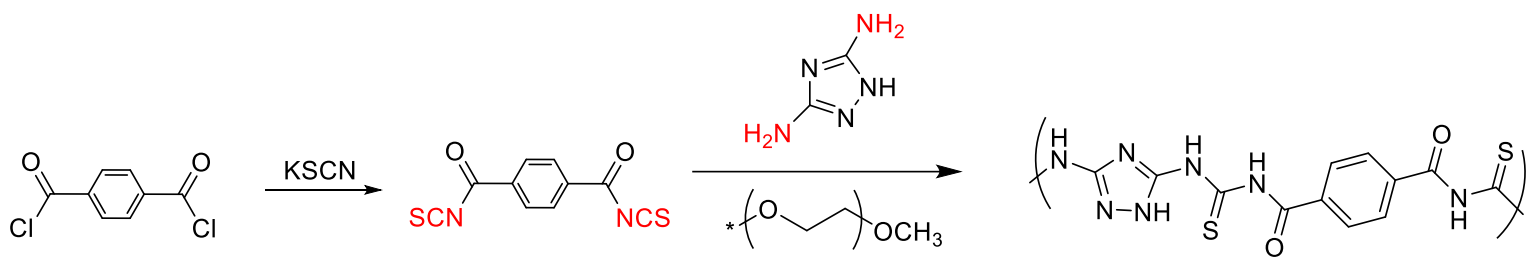

Figure 1. Synthesis of PBTU.

Polybenzoylthiourea polymer (PBTU) was synthesized through polycondensation reaction between 3,5-diamino-1,2,4-triazole and tereftaloyl diisothiocyanate in poly(ethyleneglycol)dimethylether as the phase transfer catalyst. The structure of the obtained PBTU was characterized by ${ }^{1} \mathrm{H}$ NMR and ${ }^{13} \mathrm{C}$ NMR recorded in DMSO- $d 6$. In the ${ }^{1} \mathrm{H}$ NMR spectrum (Figure 2), the chemical shifts of -NH proton signal between the carbonyl and thiocarbonyl functional groups appeared in the range of 12.5 to 11.6 $\mathrm{ppm}$. The peak of the $-\mathrm{NH}$ proton of the triazole ring was observed at $10.0 \mathrm{ppm}$. Aromatic proton signals of the PBTU belonging to the triazole and phenyl rings were assigned in the range of 8.80-7.00 ppm. ${ }^{1} \mathrm{H}$ NMR spectrum also showed some residual protons at 3.50 and $3.23 \mathrm{ppm}$ coming from the PEG phase transfer catalyst due to probably in sufficient washing with water of the final product. 


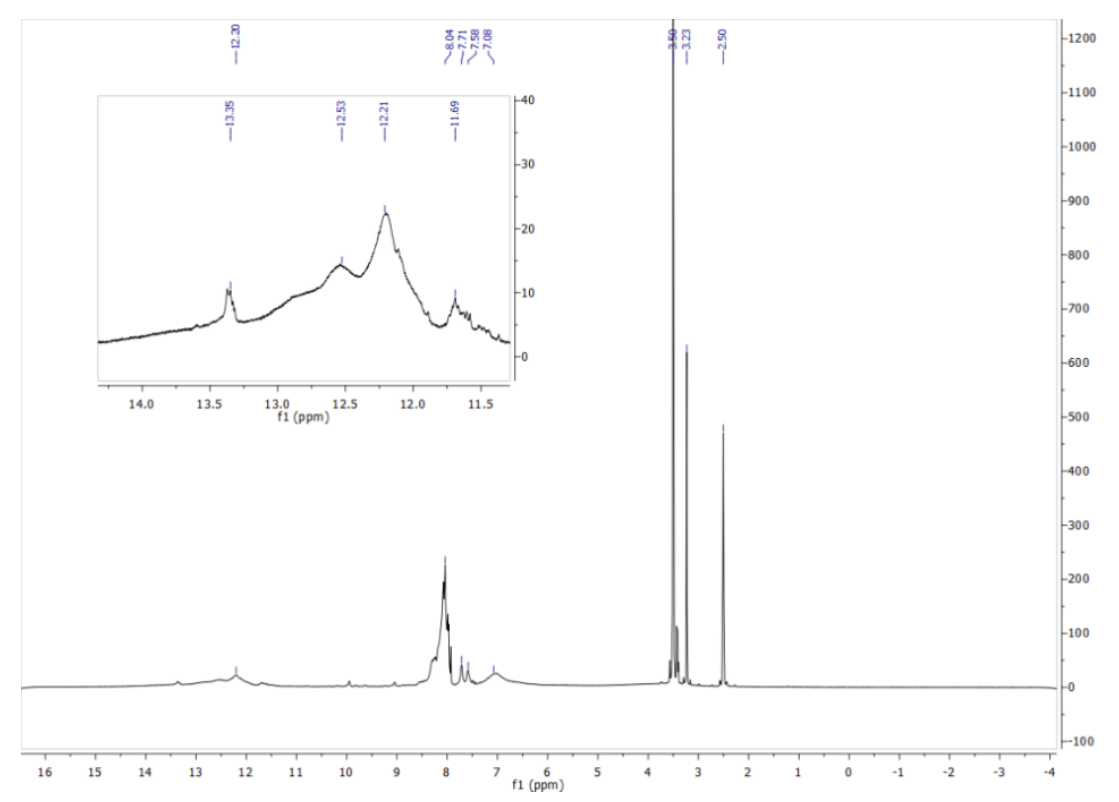

Figure 2. ${ }^{1} H$ NMR spectrum of PBTU.

Figure 3 shows the ${ }^{13} \mathrm{C}$ NMR spectrum of the PBTU.The peaks observed around 172-166 ppm can be assigned as thiocarbonyl carbons of PBTU. The presence of carbonyl carbon can be recognized in the range of 155-158 ppm. Aromatic carbon atoms in the PBTU belonging to the triazole and phenyl rings were observed between 127-138 ppm. Some carbons belonging to the residual PEG in the product were also observed in the ${ }^{13} \mathrm{C}$ NMR spectrum of the PBTU. Peaks observed at 70 and $58 \mathrm{ppm}$ were assigned to be PEG carbons. The ${ }^{1} \mathrm{H}$ and ${ }^{13} \mathrm{C}$ NMR spectra results of the obtained product confirmed the expected PBTU structure.

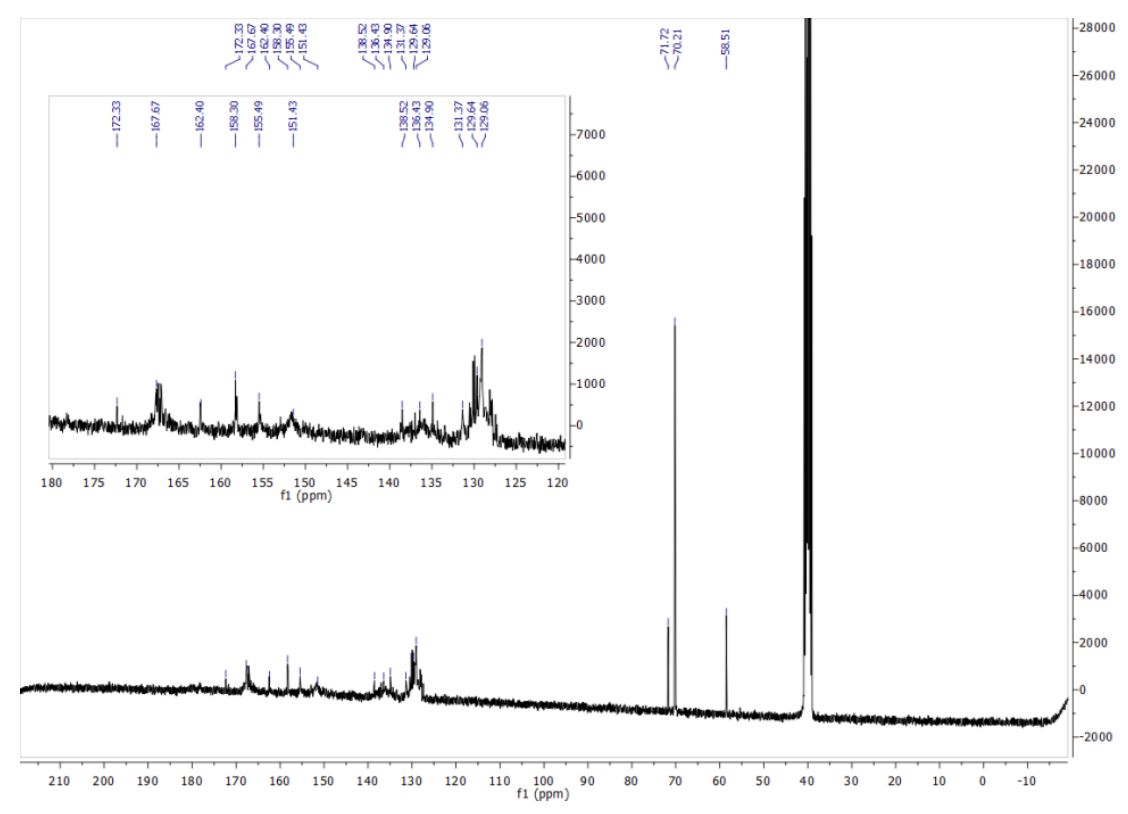

Figure 3. ${ }^{13}$ C NMR spectrum of PBTU.

Table 1.Polymerization results of benzoylthiourea.

\begin{tabular}{|c|c|c|c|c|c|c|c|c|c|}
\hline $\begin{array}{c}\text { Yield } \\
(\%)\end{array}$ & $\begin{array}{c}\boldsymbol{T}_{\mathbf{g}} \\
\left({ }^{\circ} \mathrm{C}\right)\end{array}$ & $\begin{array}{c}\boldsymbol{T}_{\mathbf{m}} \\
\left({ }^{\circ} \mathrm{C}\right)\end{array}$ & $\begin{array}{c}\boldsymbol{T}_{\mathbf{5 0}} \\
\left({ }^{\circ} \mathrm{C}\right)\end{array}$ & $\begin{array}{c}\mathbf{E} \\
(G P a)\end{array}$ & $\begin{array}{c}\mathbf{H} \\
(G P a)\end{array}$ & $\boldsymbol{M}_{\mathbf{n}}$ & $\mathbf{P D I}$ & $\begin{array}{c}\text { Surface area } \\
\left(\mathrm{m}^{2} / g\right)\end{array}$ & $\begin{array}{c}\text { Total pore volume } \\
\left(\mathrm{cm}^{3} / \mathrm{g}\right)\end{array}$ \\
\hline$\% 100$ & 229 & 304 & 440 & 2.35 & 0.136 & 101000 & 1.75 & 17.77 & 0.29 \\
\hline
\end{tabular}


Table 2. Mechanical properties of benzoylthiourea based polymers reported in the literature [8].

\begin{tabular}{|c|c|c|}
\hline Polymer & $\mathbf{E}$ & $\mathbf{H}$ \\
& $(G p a)$ & $(G p a)$ \\
\hline BTP1 & 0.48 & 0.049 \\
\hline BTP2 & 1.42 & 0.0892 \\
\hline
\end{tabular}

Thermal properties of the PBTU were evaluated by TGA and DSC analyses. According to the TGA curve of PBTU shown in Figure 4, the product showed three steps thermal degradation characteristics under nitrogen atmosphere. Thermal decomposition of the PBTU starts around $150{ }^{\circ} \mathrm{C} .10 \%$ and $50 \%$ degradations occur at 230 and $440{ }^{\circ} \mathrm{C}$, respectively. About 5\% carbonaceous residue left after heating at $900{ }^{\circ} \mathrm{C}$.

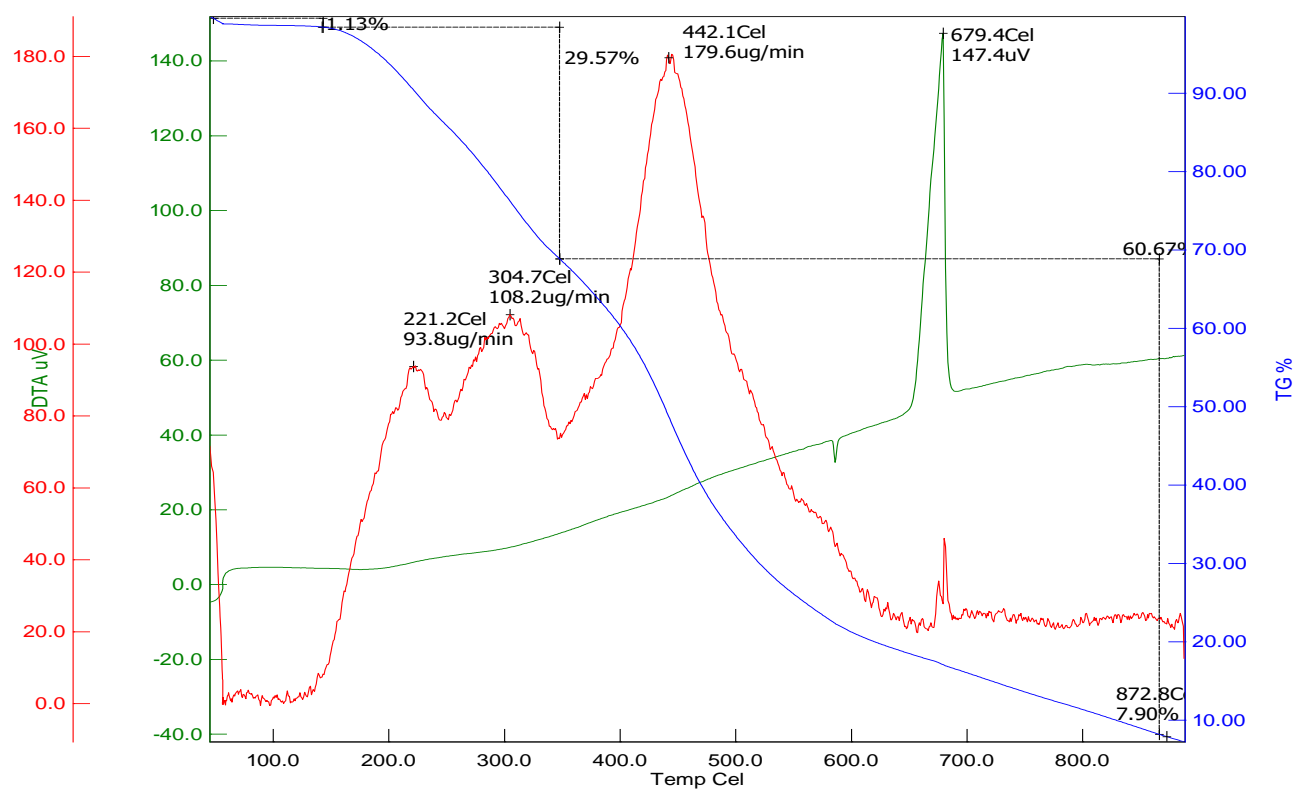

Figure 4.Thermogravimetric analysis (TGA) result of PBTU.

Differential scanning calorimetry (DSC) analysis result of the PBTU showed both glass transition and melting temperatures. The glass transition temperature $\left(T_{\mathrm{g}}\right)$ of PBTU was observed at $229{ }^{\circ} \mathrm{C}$ according to the DSC (Figure 5). Observation of the high $T_{\mathrm{g}}$ is probably due to the strong intermolecular forces in the polymeric structure such as hydrogen bonds, the presence of amide and carbonyl groups reducing chain flexibility, the presence of phenyl groups reducing the freedom of rotation, and the high molecular weight of the polymer. The glass transition temperatures of the reported polybenzoylthiourea derivatives was not observed in previous reports [14]. The melting temperature of the PBTU was observed at $304^{\circ} \mathrm{C}$ under nitrogen atmosphere (Figure 5). 


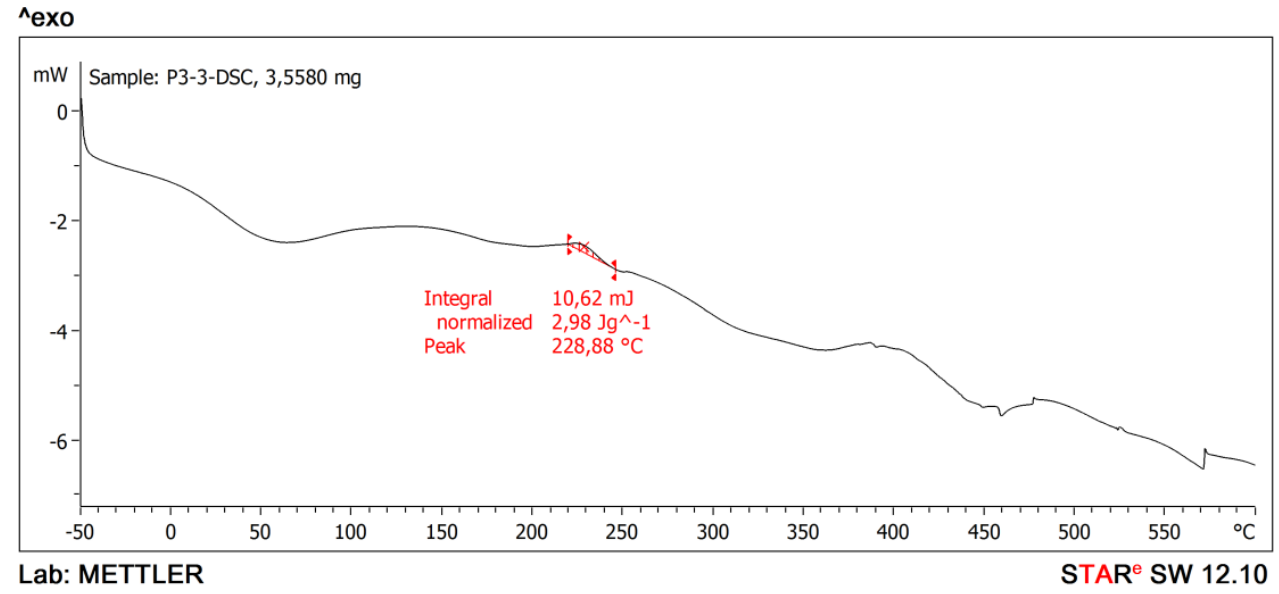

Figure 5. DSC curve of PBTU.

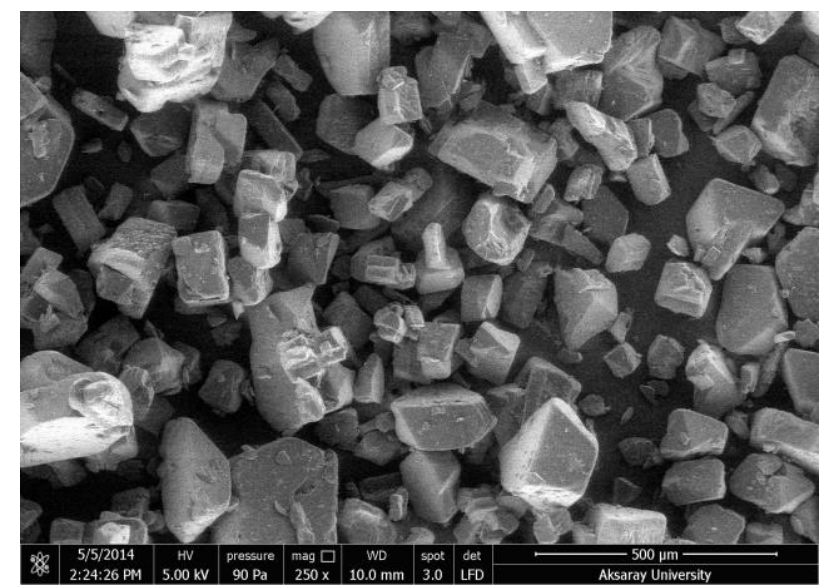

(a)

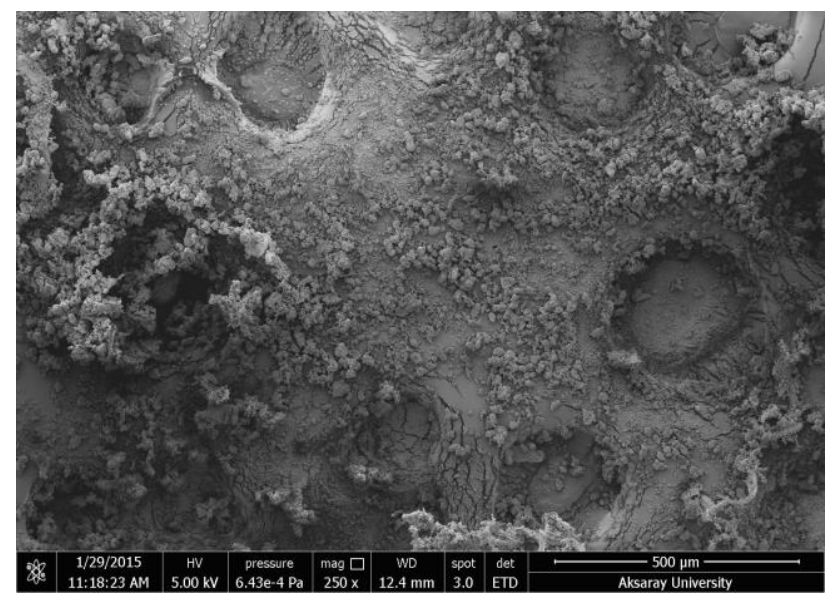

(b)

Figure 6. Comparison of SEM images of (a)3,5-diamino-1,2,4-triazole and (b)PBTU.

Scanning electron microscopy (SEM) analysis (Figure 6) was carried out to detect the morphological properties of the synthesized product and the diamine starting reagent. The Figure $6 \mathrm{~b}$ illustrates the morphology of the obtained PBTU. According to the SEM image of the PBTU, the morphology of the obtained PBTU (Figure 6b) is completely different compared to the morphology of 3,5-diamino-1,2,4triazole (Figure 6a) starting material. When the morphological properties of PBTU, BTP1 and BTP2 
polymers are compared, it can be seen that the morphological properties of these polymers are resemble to each other and they have dense and homogeneous structures.

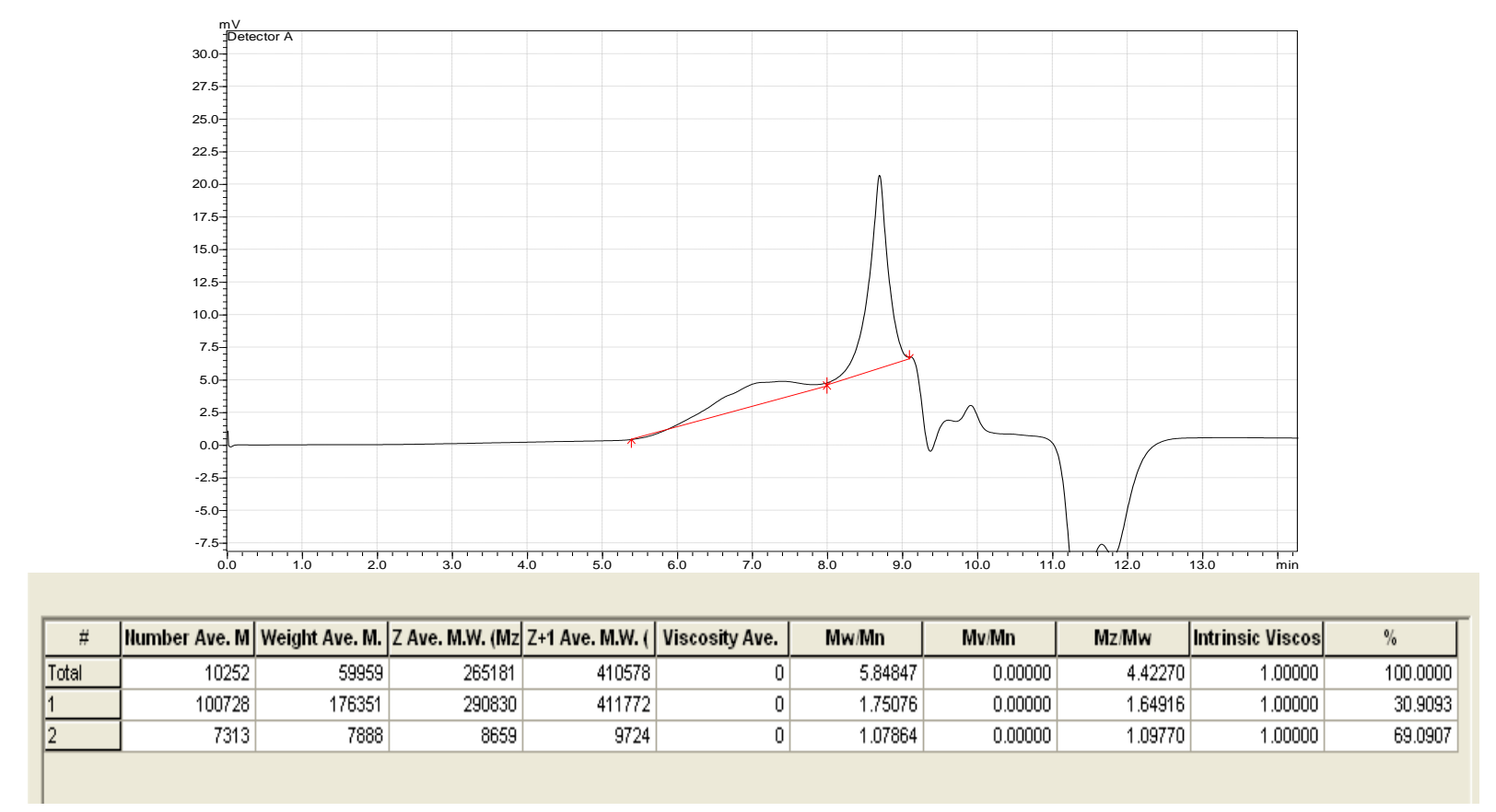

Figure 7. Molecular weight analysis of PBTU.

Molecular weight measurement of the obtained product was carried out with GPC instrument in DMF solvent with calibration of narrow polydispersity polystyrene (PS) standards (Figure 7). GPC trace of the product showed bimodal molecular weight distribution. As explained above, the product contained a small amount of PEG residue according to the ${ }^{1} \mathrm{H}$ and ${ }^{13} \mathrm{C}$ NMR spectra. Due to the PEG residue, obtained product possessed bimodal molecular weight distribution. Probably, the lower molecular weight belongs to the trace amounts of PEG residue and the main polymer showed very high number average molecular weight, $M_{\mathrm{n}}: 101000 \mathrm{~g} / \mathrm{mol}$. Polydispersity index (PDI) of the obtained polymer was found to be 1.75 .

Mechanical measurements of cylindrical PBTU, BTP1 and BTP2 capsules $(13.0 \mathrm{~mm} \times 1.2 \mathrm{~mm}$ dimension) were evaluated by nanoindentation technique with HYSITRON TI 950 TriboIndenter instrument. Nanoindentation is an effective technology for the determination of the mechanical properties of thin films and coatings. Mechanical properties of the obtained capsules of PBTU, BTP1 and BTP2 polymers were investigated using this method. Elastic modulus (E) and hardness (H) of the polymer capsule were found to be $2.35 \mathrm{GPa}$ and $0.136 \mathrm{GPa}$, respectively (Table 1). Mechanical properties of BTP1 and BTP2 polymers reported in the literatureare given in Table 2. Comparing to the mechanical properties of BTP1 and BTP2 (Table 2), obtained polymer PBTU showed better mechanical properties and had higher elastic modulus and hardness. PBTU polymer containing triazole ring in the backbone indicated improvement in the mechanical properties. In addition to that, the average size of the porosity could be a possible reason for the mechanical strength since polymer having smaller pore sizes showed higher elastic modulus and hardness. Another reason of showing increasing mechanical strength for the PBTU was probably due to the increasing crystallinity.

The synthesized PBTU was insoluble in water and organic solvents including alcohol, acetonitrile, acetone, etc., but it was dissolved in dimethyl sulfoxide (DMSO) and N,N-dimethylformamide (DMF). It has been reported in the literature that BTP1 and BTP2 polymers were not soluble even in DMSO and DMF. The reason of having insoluble nature and not showing glass transition temperatures of these polymers was not only the result of intramolecular and intermolecular interactions of the benzoylthiourea chains or possible crosslinking, but also the weak interaction with the solvent 
molecules. The polymer synthesis containing $1,2,4$ triazole unit in the polymer backbone enabled the formation of soluble benzoylthiourea polymer. Since the PBTU polymer was soluble, its average molecular weights were determined. Physical properties of polymers are mainly related to having high average molecular weights. PBTU has a high molecular weight. Obtaining higher molecular weight results in the higher the attraction forces between the polymer chains. As a result of that, the elastic modulus increases and the material hardens. Polymer becomes harder and more durable with increasing the average molecular weight.

Surface area evaluation and the pore size distribution of the polymer were measured by the BrunauerEmmett-Teller (BET) method under nitrogen atmosphere (Table 1). These properties were determined by nitrogen adsorption at $77 \mathrm{~K}$ bath temperature and degassing temperatures in $80^{\circ} \mathrm{C}$.Total pore volume of the PBTU was measured as $0.29 \mathrm{~cm}^{3} / \mathrm{g}$. In addition to that, the surface area of the product was calculated as $17.77 \mathrm{~m}^{2} / \mathrm{g}$. PBTU can be considered as mesoporous materials since it has some characteristics of those materials. Therefore, PBTU can be possibly used for membrane applications

\section{CONCLUSION}

Polybenzoylthiourea was synthesized from the reaction between a diamine (3,5-diamino-1,2,4triazole) and a diisothiocyanate (tereftaloyl diisothiocyanate) in the presence of poly(ethyleneglycol) dimethylether phase transfer catalyst. According to the literature, similar polybenzoylthiourea based polymers were insoluble in common organic solvents and did not show glass transition temperatures. In this study, obtained polybenzoylthiourea (PBTU) was highly soluble in organic solvents including DMSO and DMF. The glass transition temperature $\left(T_{\mathrm{g}}\right)$ and the melting temperature $\left(T_{\mathrm{m}}\right)$ of the PBTU was observed at $229^{\circ} \mathrm{C}$ and $304{ }^{\circ} \mathrm{C}$, respectively. Total pore volume and surface area of the polymer was calculated as $0.29 \mathrm{~cm}^{3} / \mathrm{g}$ and $17.77 \mathrm{~m}^{2} / \mathrm{g}$, respectively, which are higher than the reported values for different types of polybenzoylthioureas in the literature. Hardness and elastic modulus of the obtained PBTU capsule were measured respectively as $2.353 \mathrm{GPa}$ and $0.136 \mathrm{GPa}$ using nanoindentation technique. PBTU polymer can be possibly used in a variety of industrial applications including water treatment, waste water treatment, desalination and bio-separation due to its homogeneous and stable structure, coordination properties, high thermal stability, adsorption properties and specific surface area and pore volumes.

ACKNOWLEDGEMENTS: This work was supported by Aksaray University Coordinator ship of Scientific Research Projects (Project no: 2012/06). The abstract of this research was presented at the 31st National Chemistry Congress 2019 as a poster presentation.

\section{V.REFERENCES}

[1] H.Refiker, M.Merdivan, and RS.Aygun,"Selective preconcentration of gold from ore samples,"International Journal of Analytical Chemistry,vol.10, pp.1-8, 2018.

[2] TO.Brito, LO.Abreu, KM.Gomes, MCS.Lourenço, PML.Pereira, SF.Yamada-Ogatta, A.Fátima, CA.Tisher, JrF.Macedo, MLF.Bispo,"Benzoylthioureas: design, synthesis and antimycobacterial evaluation,"Med.Chem, vol.16, no.1, pp. 93-103, 2020.

[3] S.Belveren, HA.Dondasa, M.Ülger, S.Poyraz, E.García-Mingüens, M.Ferrandiz-Saperas, JM.Sansano,"Synthesis of highly functionalized 2-(pyrrolidin-1-yl)thiazoleframeworks with interesting antibacterial and antimycobacterial activity," Tetrahedron,vol.73, no.48, pp.6718-6727, 2017 
[4] P.Tashakkori, SS.Bozkurt, M.Merdivan, G.Binzet, and N.Kulcu,"Separation and preconcentration of palladium using benzoylthiourea immobilized on a cationic surfactant coated silica gel,"Analytical Methods, vol.12, no.4, pp.4135-4139, 2012.

[5] HN.Hung, U.Abram, "Rhenium and Technetium Complexes with N,N-Dialkyl-N-benzoyl thioureas,"Inorg.Chem.,vol.46, no.13, pp.5310-5319, 2007

[6] S.Ayata, S.Aydinci, M.Merdivan, G.Binzet, N.Külcü,"Sorption of uranium using silica gel with benzoylthiourea derivatives,"Journal of Radioanalytical and Nuclear Chemistry, vol.285, no.3, pp.525-529, 2010.

[7] C.Fontàs, M.Hidalgo, V.Salvadó, E.Anticó, "Selective recovery and preconcentration of mercury with a benzoylthiourea-solid supported liquid membrane system,"Analytica Chimica Acta, vol.547, no.2, pp.255-261, 2005.

[8] G.Kurt,"Synthesis of new poly-benzoylthiourea and thermal and surface properties,"J.Polym.Res.,vol.26, no.232, pp.1-10, 2019.

[9] KJ.Shneine, YH.Alaraji, "Chemistry of 1,2,4-Triazole: A Review Article,"International Journal of Science and Research, vol.5, no.3, pp.1411-1423, 2016.

[10] SP.Pardeshi, SV.Patil, R.Patil, VD.Bobade, "Synthesis and Antimicrobial Activities of Some 1,2,4- Triazolo[3,4-b][1,3,4]thiadiazoles and 1,2,4-Triazolo [3,4-b][1,3,4]thiadiazines Bearing Bistrifluoromethyl phenyl Moiety," J.Chem.Pharma. Res., vol.6, no.4, pp.675-681, 2014.

[11] T.Taj, RR.Kamble, T.Gireesh, BV.Badami, "An Expeditious Green Synthesis of Schiff Bases and Azetidinones Derivatised with 1,2,4-Triazoles," J.Chem.Sci., vol.123, no.5, pp.657-666, 2011.

[12] X.Zhou, L.Wan, Y.Hu, Y.E, F.Huang, L.Du, "Synthesis and characterization of novel polytriazoleimides by CuAAC step-growth polymerization," Polymer Journal, vol.42, No.3, pp.216222,2010

[13] S.Chisca, T.Marchesi, G.Falca, VE.Musteata, T.Huang, E.Abou-Hamad, SP. Nunes, "Organic solvent and thermal resistant polytriazole membranes with enhanced mechanical properties cast from solutions in non-toxic solvents," Journal of Membrane Science, vol.597, no.117634, pp.1-12, 2020. 